\title{
Survey of the Degree of Examinees' Satisfaction with Instructions on How to Read Results of General Health Checkups at a Workplace
}

\author{
Yasushi KUDO $^{1 *}$, Toshihiko SATOH ${ }^{1}$, Mitsushi OKADA ${ }^{1}$, Satoshi SHINOHARA ${ }^{1,2}$, \\ Izumi MORITA², Eriko MIYAJIMA ${ }^{1}$, Mitsuyasu WATANABE ${ }^{1}$, Takeo MIKI ${ }^{1}$, \\ Yuichi MIWA ${ }^{1}$ and Yoshiharu AIZAWA ${ }^{1}$
}

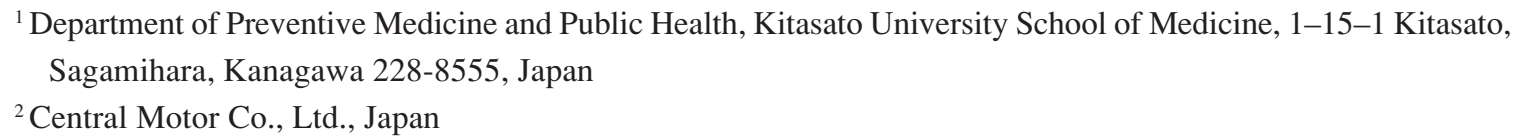

Received June 23, 2006 and accepted March 27, 2007

\begin{abstract}
To clarify measures for making clearer instructions on how to read the results of general health checkups in a workplace by surveying the views of workers on these instructions, an anonymous self-administered questionnaire survey was conducted at a Japanese manufacturing plant. The responses of 984 male workers were analyzed. The average age of the subjects was $32.1 \mathrm{yr}$ (range, 19-60 yr). Regarding the instructions, $4.1 \%$ of the subjects answered "definitely sufficient," $58.9 \%$ "somewhat sufficient," $28.0 \%$ "neither sufficient nor insufficient," $8.1 \%$ "somewhat insufficient" and $0.8 \%$ "definitely insufficient." Multiple regression analysis showed that the degree of examinees" satisfaction significantly correlated with the health condition (standard partial regression coefficient $=0.189, p<0.001$ ), knowledge of health management ( standard partial regression coefficient $=0.095$, $p=0.014$ ), and fear of lifestyle-related diseases (standard partial regression coefficient $=0.095, p=0.009$ ). The adjusted $R$ square value of the multiple regression analysis was 0.064 . It is necessary to provide more detailed information to those with poor health. Because the instructions contain many difficult medical terms, health professionals must give instructions that are easy to understand. Those feeling fear of lifestyle-related diseases may already know how to read checkup results. It is necessary to promote awareness of lifestyle-related diseases targeting people unfamiliar with such diseases.
\end{abstract}

Key words: Examinee satisfaction, Workplace, General health checkups, Instructions, Examination results

\section{Introduction}

In Japan, the Industrial Safety and Health Law obliges all workers to undergo general health checkups at their workplaces annually. The results of these checkups serve as a reference for occupational health staff for actions after health checkups, such as health guidance and personnel relocation, which are conducted to protect workers' health. In addition, workers are notified of their checkup results. To take full advantage of these checkups, workers should

*To whom correspondence should be addressed. fully understand the results of their general health checkups and use them for the management of their own health.

It has been reported that there are many workers who do not accurately remember the results of their general health checkups $^{1,2)}$. The reason that workers do not accurately remember their examination results may be that workers do not fully understand them.

Therefore, when workers are given the results of their general health checkups, it is important to prepare and distribute understandable instructions on how to read the report. However, to date there have been no surveys on the views of workers on such instructions. The objective of 
this study was to clarify measures for facilitating a better understanding of instructions by surveying the views of workers on the instructions.

\section{Subjects and Methods}

\section{Subjects and distribution/recovery of questionnaire}

During general health checkups conducted over $6 \mathrm{~d}$ in May 2006, a questionnaire survey was conducted on 1,131 employees at a Japanese manufacturing plant, excluding the occupational health staff.

The plant is a machine manufacturer. The plant mainly recruits high-school graduates as blue-collar workers and university graduates and postgraduates as white-collar workers. Only blue-collar workers are assigned to night shifts.

The Industrial Safety and Health Law of Japan stipulates that workers shall undergo the following tests: body height, weight, visual acuity measurements, audiometry, sphygmomanometry, chest X-ray examination, urinalysis, anemia examination, liver function tests, blood lipid examination, blood sugar test, and electrocardiography. However, the law also stipulates that anemia examination, liver function tests, blood lipid examination, blood sugar test, and electrocardiography in workers less than $40 \mathrm{yr}$ old, excluding those $35 \mathrm{yr}$ old, may be excluded according to a physicians' judgment. The workers of this plant underwent all the tests.

When the employees underwent general health checkups, they were first registered at the reception desk. At the time of registration, the employees received anonymous selfadministered questionnaires (Appendix 1), envelopes for the return of the questionnaires, instructions (Appendix 2), and documents explaining the purpose of this study, the privacy policy and informed consent.

The workers of this plant undergo annual general health checkups given by the same medical institution, which then distributes the instructions (Appendix 2) with the results of the workers' checkups. Each examinee was required to read the instructions and then answer the questionnaire (Appendix 1). The examinees placed the completed questionnaire into the envelope, sealed it, and put it into a collection box at the reception desk.

One thousand eighty-five of the 1,131 examinees answered questionnaires (95.9\%). Questionnaires that had missing values were excluded from the analyses. Because the number of female workers was very small (17), they were excluded from the study. Consequently, a total of 984 questionnaires were analyzed. The subjects' average age was $32.1 \mathrm{yr}$ (range, 19-60 yr) (Table 1).
Table 1. Distribution of analyzed subjects

\begin{tabular}{rlll}
\hline Age & Blue-collar workers & White-collar workers & Total \\
\hline-29 & $375(45.8 \%)$ & $36(21.7 \%)$ & $411(41.8 \%)$ \\
$30-39$ & $307(37.5 \%)$ & $106(63.9 \%)$ & $413(42.0 \%)$ \\
$40-49$ & $86(10.5 \%)$ & $18(10.8 \%)$ & $104(10.6 \%)$ \\
$50-$ & $50(6.1 \%)$ & $6(3.6 \%)$ & $56(5.7 \%)$ \\
\hline Total & $818(100 \%)$ & $166(100 \%)$ & $984(100 \%)$ \\
\hline
\end{tabular}

\section{Questionnaire items}

There has been no previous study on the degree of examinees' satisfaction with the instructions on how to read the results of their general health checkups. Thus, we prepared a questionnaire (Appendix 1), the contents of which were classified into three categories: basic attributes of subjects (Question set 1), subjects' views of health (Question set 2), and degree of satisfaction with the instructions (Question 3).

The items of Question set 1 were as follows: age, gender, marital status, abnormal findings in the past health checkups, occupation, and presence or absence of lifestyle-related diseases. The items of Question set 2 were as follows: health condition, interest in health, knowledge of health management, and fear of lifestyle-related diseases. The subjects' views of health were graded on a 5-point scale from 5 (positive) to 1 (negative). Question 3 was about the degree of examinees' satisfaction with the instructions. The subjects selected one of among five possible answers from "definitely sufficient" to "definitely insufficient."

\section{Statistical analysis}

To evaluate the association between the degree of the examinee's satisfaction with the instructions and the basic attributes of the subjects, the Mann-Whitney U test or Kruskal-Wallis test was performed. The Kruskal-Wallis test was performed for ages less than or equal to 29, 30-39, 4049 , and 50 or older. The Mann-Whitney U test was performed for marital status, abnormal findings in the past health checkups, occupation, and presence or absence of lifestylerelated diseases. To evaluate the association between the degree of examinees' satisfaction with the instructions and the subjects' views of health, the Kruskal-Wallis test was performed.

The standard partial regression coefficient was determined by multiple linear regression analysis, with the degree of examinees' satisfaction with the instructions as the dependent variable, and the basic attributes of the subjects and the subjects' views of health as independent variables. 
Table 2. Relationships between the degree of examinees' satisfaction with the instructions on how to read examination results and the basic attributes of the subjects

\begin{tabular}{|c|c|c|c|c|c|c|c|}
\hline & \multicolumn{5}{|c|}{$\begin{array}{l}\text { Degree of examinees' satisfaction with the instructions } \\
\text { on how to read examination results }\end{array}$} & \multirow[b]{2}{*}{ Total } & \multirow[b]{2}{*}{$p$ value } \\
\hline & $\begin{array}{l}\text { Definitely } \\
\text { sufficient }\end{array}$ & $\begin{array}{l}\text { Somewhat } \\
\text { sufficient }\end{array}$ & $\begin{array}{c}\text { Neither } \\
\text { sufficient nor } \\
\text { insufficient }\end{array}$ & $\begin{array}{l}\text { Somewhat } \\
\text { insufficient }\end{array}$ & $\begin{array}{c}\text { Definitely } \\
\text { insufficient }\end{array}$ & & \\
\hline \multicolumn{8}{|l|}{ Age } \\
\hline-29 & $23(5.6 \%)$ & $245(59.6 \%)$ & $116(28.2 \%)$ & $24(5.8 \%)$ & $3(0.7 \%)$ & $411(100 \%)$ & \\
\hline $30-39$ & $13(3.1 \%)$ & $237(57.4 \%)$ & $116(28.1 \%)$ & $44(10.7 \%)$ & $3(0.7 \%)$ & $413(100 \%)$ & \\
\hline $40-49$ & $2(1.9 \%)$ & $61(58.7 \%)$ & $29(27.9 \%)$ & $10(9.6 \%)$ & $2(1.9 \%)$ & $104(100 \%)$ & 0.096 \\
\hline $50-$ & $2(3.6 \%)$ & $37(66.1 \%)$ & $15(26.8 \%)$ & $2(3.6 \%)$ & $0(0.0 \%)$ & $56(100 \%)$ & \\
\hline \multicolumn{8}{|l|}{ Marital status } \\
\hline Married & $17(4.0 \%)$ & $244(58.0 \%)$ & $121(28.7 \%)$ & $37(8.8 \%)$ & $2(0.5 \%)$ & $421(100 \%)$ & \\
\hline Single & $23(4.1 \%)$ & $336(59.7 \%)$ & $155(27.5 \%)$ & $43(7.6 \%)$ & $6(1.1 \%)$ & $563(100 \%)$ & 0.599 \\
\hline \multicolumn{8}{|c|}{ Abnormal findings in past health checkups } \\
\hline Yes & $5(1.5 \%)$ & $198(59.1 \%)$ & $93(27.8 \%)$ & $36(10.7 \%)$ & $3(0.9 \%)$ & $335(100 \%)$ & \\
\hline No & $35(5.4 \%)$ & $382(58.9 \%)$ & $183(28.2 \%)$ & $44(6.8 \%)$ & $5(0.8 \%)$ & $649(100 \%)$ & 0.037 \\
\hline \multicolumn{8}{|l|}{ Occupation } \\
\hline Blue-collar workers & $33(4.0 \%)$ & $479(58.6 \%)$ & $236(28.9 \%)$ & $64(7.8 \%)$ & $6(0.7 \%)$ & $818(100 \%)$ & \\
\hline White-collar workers & $7(4.2 \%)$ & $101(60.8 \%)$ & $40(24.1 \%)$ & $16(9.6 \%)$ & $2(1.2 \%)$ & $166(100 \%)$ & 0.747 \\
\hline \multicolumn{8}{|c|}{ Presence or absence of lifestyle-related diseases } \\
\hline Yes & $2(3.2 \%)$ & $41(66.1 \%)$ & $14(22.6 \%)$ & $3(4.8 \%)$ & $2(3.2 \%)$ & $62(100 \%)$ & \\
\hline No & $38(4.1 \%)$ & $539(58.5 \%)$ & $262(28.4 \%)$ & $77(8.4 \%)$ & $6(0.7 \%)$ & $922(100 \%)$ & 0.414 \\
\hline Total & $40(4.1 \%)$ & $580(58.9 \%)$ & $276(28.0 \%)$ & $80(8.1 \%)$ & $8(0.8 \%)$ & $984(100 \%)$ & \\
\hline
\end{tabular}

In multiple regression analysis, with regard to the instructions, 5 to 1 points were given in the order from "definitely sufficient" to "definitely insufficient." As for age, the actual age was used. Marital status, abnormal findings in the past health checkups, occupation, and presence or absence of lifestyle-related diseases were used as dichotomous variables. The coding of dichotomous variables was as follows: marital status (Married $=1$, Single $=0$ ); abnormal findings in the past health checkups (Yes $=1$, No $=0$ ); occupation (Blue-collar worker $=1$, White-collar worker $=0$ ); presence or absence of lifestyle-related diseases (Yes $=1$, No $=0$ ). With regard to health condition, 5 to 1 points were given in the order from "good" to "poor." Regarding interest in health, knowledge of health management, and fear of lifestyle-related diseases, 5 to 1 points were given in the order from "considerable" to "none."

This scoring method is based on the hypothesis that the scale of each question on satisfaction is continuous and that it has an even interval ${ }^{3}$. This approach is practical and is used in various studies ${ }^{4-9}$.

SPSS 11.5 J for Windows was used for all analyses.

\section{Results}

The association between the degree of examinees' satisfaction with the instructions and the basic attributes of the subjects is shown in Table 2. The association between the degree of examinees' satisfaction with the instructions and the subjects' views of health is shown in Table 3.

With regard to the instructions, $4.1 \%$ of the subjects answered "definitely sufficient," $58.9 \%$ "somewhat sufficient," $28.0 \%$ "neither sufficient nor insufficient," $8.1 \%$ "somewhat insufficient," and $0.8 \%$ "definitely insufficient."

In Table 2, the Mann-Whitney U test shows there was a significant difference in the degree of examinees' satisfaction with respect to abnormal findings in the past health checkups ( $p=0.037$ ). While the percentage of subjects who considered the instructions to have been "definitely sufficient" was only $1.5 \%$ among those with abnormalities, it was $5.4 \%$ among those with no abnormalities. The percentage of those who considered the instructions to have been "somewhat insufficient" also differed considerably between those with (10.7\%) abnormalities and those without $(6.8 \%)$ abnormalities. 
Table 3. Relationships between the degree of examinees' satisfaction with the instructions on how to read examination results and subjects' views of health

\begin{tabular}{|c|c|c|c|c|c|c|c|}
\hline & \multicolumn{5}{|c|}{$\begin{array}{l}\text { Degree of examinees' satisfaction with the instructions } \\
\text { on how to read examination results }\end{array}$} & \multirow[b]{2}{*}{ Total } & \multirow[b]{2}{*}{$p$ value } \\
\hline & $\begin{array}{l}\text { Definitely } \\
\text { sufficient }\end{array}$ & $\begin{array}{l}\text { Somewhat } \\
\text { sufficient }\end{array}$ & $\begin{array}{c}\text { Neither } \\
\text { sufficient nor } \\
\text { insufficient }\end{array}$ & $\begin{array}{l}\text { Somewhat } \\
\text { insufficient }\end{array}$ & $\begin{array}{l}\text { Definitely } \\
\text { insufficient }\end{array}$ & & \\
\hline \multicolumn{8}{|l|}{ Health condition } \\
\hline Good & $26(14.7 \%)$ & $102(57.6 \%)$ & $40(22.6 \%)$ & $8(4.5 \%)$ & $1(0.6 \%)$ & $177(100 \%)$ & \multirow{5}{*}{$<0.001$} \\
\hline Somewhat good & $8(1.8 \%)$ & $297(65.7 \%)$ & $115(25.4 \%)$ & $28(6.2 \%)$ & $4(0.9 \%)$ & $452(100 \%)$ & \\
\hline Average & $4(1.6 \%)$ & $136(53.5 \%)$ & $88(34.6 \%)$ & $26(10.2 \%)$ & $0(0.0 \%)$ & $254(100 \%)$ & \\
\hline Somewhat poor & $1(1.1 \%)$ & $38(43.7 \%)$ & $28(32.2 \%)$ & $17(19.5 \%)$ & $3(3.4 \%)$ & $87(100 \%)$ & \\
\hline Poor & $1(7.1 \%)$ & $7(50.0 \%)$ & $5(35.7 \%)$ & $1(7.1 \%)$ & $0(0.0 \%)$ & $14(100 \%)$ & \\
\hline \multicolumn{8}{|l|}{ Interest in health } \\
\hline Considerable & $9(13.4 \%)$ & $37(55.2 \%)$ & $14(20.9 \%)$ & $6(9.0 \%)$ & $1(1.5 \%)$ & $67(100 \%)$ & \multirow{5}{*}{0.006} \\
\hline Moderate & $13(3.5 \%)$ & $242(65.6 \%)$ & $78(21.1 \%)$ & $33(8.9 \%)$ & $3(0.8 \%)$ & $369(100 \%)$ & \\
\hline Average & $15(3.2 \%)$ & $268(56.9 \%)$ & $152(32.3 \%)$ & $34(7.2 \%)$ & $2(0.4 \%)$ & $471(100 \%)$ & \\
\hline Slight & $0(0.0 \%)$ & $29(47.5 \%)$ & $25(41.0 \%)$ & $6(9.8 \%)$ & $1(1.6 \%)$ & $61(100 \%)$ & \\
\hline None & $3(18.8 \%)$ & $4(25.0 \%)$ & $7(43.8 \%)$ & $1(6.3 \%)$ & $1(6.3 \%)$ & $16(100 \%)$ & \\
\hline \multicolumn{8}{|c|}{ Knowledge of health management } \\
\hline Considerable & $7(26.9 \%)$ & $16(61.5 \%)$ & $2(7.7 \%)$ & $0(0.0 \%)$ & $1(3.8 \%)$ & $26(100 \%)$ & \multirow{5}{*}{$<0.001$} \\
\hline Moderate & $8(5.0 \%)$ & $105(65.6 \%)$ & $35(21.9 \%)$ & $11(6.9 \%)$ & $1(0.6 \%)$ & $160(100 \%)$ & \\
\hline Average & $19(3.1 \%)$ & $375(61.4 \%)$ & $173(28.3 \%)$ & $39(6.4 \%)$ & $5(0.8 \%)$ & $611(100 \%)$ & \\
\hline Slight & $0(0.0 \%)$ & $67(47.5 \%)$ & $50(35.5 \%)$ & $24(17.0 \%)$ & $0(0.0 \%)$ & $141(100 \%)$ & \\
\hline None & $6(13.0 \%)$ & $17(37.0 \%)$ & $16(34.8 \%)$ & $6(13.0 \%)$ & $1(2.2 \%)$ & $46(100 \%)$ & \\
\hline \multicolumn{8}{|c|}{ Fear of lifestyle-related diseases } \\
\hline Considerable & $10(14.9 \%)$ & $38(56.7 \%)$ & $15(22.4 \%)$ & $3(4.5 \%)$ & $1(1.5 \%)$ & $67(100 \%)$ & \multirow{5}{*}{$<0.001$} \\
\hline Moderate & $12(3.7 \%)$ & $219(68.0 \%)$ & $62(19.3 \%)$ & $28(8.7 \%)$ & $1(0.3 \%)$ & $322(100 \%)$ & \\
\hline Average & $12(2.8 \%)$ & $251(57.8 \%)$ & $136(31.3 \%)$ & $31(7.1 \%)$ & $4(0.9 \%)$ & $434(100 \%)$ & \\
\hline Slight & $2(1.8 \%)$ & $52(45.6 \%)$ & $48(42.1 \%)$ & $11(9.6 \%)$ & $1(0.9 \%)$ & $114(100 \%)$ & \\
\hline None & $4(8.5 \%)$ & $20(42.6 \%)$ & $15(31.9 \%)$ & $7(14.9 \%)$ & $1(2.1 \%)$ & $47(100 \%)$ & \\
\hline Total & $40(4.1 \%)$ & $580(58.9 \%)$ & $276(28.0 \%)$ & $80(8.1 \%)$ & $8(0.8 \%)$ & $984(100 \%)$ & \\
\hline
\end{tabular}

In Table 3, the Kruskal-Wallis test shows that there were significant differences in the degree of examinees' satisfaction with respect to health condition $(p<0.001)$, interest in health $(p=0.006)$, knowledge of health management $(p<0.001)$, and fear of lifestyle-related diseases $(p<0.001)$. The percentage of the subjects feeling that instructions were insufficient increased as their answers to items regarding health condition, knowledge of health management, and fear of lifestyle-related diseases became more negative. However, it showed no such trend for interest in health, that is, the percentages of subjects who considered the instructions to be "somewhat insufficient" were similar regardless of their interest in health. Furthermore, the percentage of subjects who considered the instructions to be "definitely sufficient" showed two peaks with respect to the interest in health: $13.4 \%$ for "considerable" and $18.8 \%$ for "none."
The results of multiple regression analysis are shown in Table 4. The degree of examinees' satisfaction significantly correlated with health condition (standard partial regression coefficient $=0.189, p<0.001)$, knowledge of health management (standard partial regression coefficient $=0.095$, $p=0.014$ ), and fear of lifestyle-related diseases (standard partial regression coefficient $=0.095, p=0.009)$. The adjusted $\mathrm{R}$ square value of the multiple regression analysis was 0.064 .

\section{Discussion}

Patients' satisfaction is recognized as an important index for gauging the quality of medical services, and many studies on this have been reported ${ }^{8-11)}$. Concerning surveys of the degree of examinees' satisfaction with health checkups at workplaces, there are the reports of Ezaki et al. ${ }^{12)}$ and our 
Table 4. Factors associated with the degree of examinees' satisfaction with the instructions on how to read examination results

\begin{tabular}{lccc}
\hline & $\begin{array}{c}\text { Standard partial } \\
\text { regression coefficient }\end{array}$ & $p$ value & VIF \\
\hline Age & -0.036 & 0.347 & 1.571 \\
Marital status & -0.004 & 0.908 & 1.243 \\
Abnormal findings in the past health checkups & -0.042 & 0.234 & 1.305 \\
Occupation & -0.028 & 0.378 & 1.036 \\
Presence or absence of lifestyle-related diseases & 0.064 & 0.058 & 1.192 \\
Health condition & 0.189 & $<0.001$ & 1.191 \\
Interest in health & -0.016 & 0.664 & 1.371 \\
Knowledge of health management & 0.095 & 0.014 & 1.581 \\
Fear of lifestyle-related diseases & 0.095 & & 1.375 \\
\hline Adjusted R square & 0.064 & \\
\hline
\end{tabular}

VIF, variance inflation factor.

previous report ${ }^{7}$. However, in these studies, the degree of satisfaction was surveyed when subjects underwent checkups. To improve the quality of general health checkups and encourage examinees to utilize them effectively, it is necessary to evaluate the degree of examinees' satisfaction with the instructions.

The degree of examinees' satisfaction significantly correlated with the health condition $(p<0.001)$. Because those in poor health may have some anxiety about their health, it is speculated that such subjects desire more detailed information.

It is important to provide those in poor health with detailed information before they develop serious diseases. Conversely, those in good health may not share the same sense of necessity of undergoing general health checkups. The extent and frequency of general health checkups that healthy people demand are lower than those that unhealthy people demand. Therefore, healthy people may favorably evaluate the instructions although they did not fully comprehend the results of the health checkups.

The degree of examinees' satisfaction significantly correlated with the knowledge of health management $(p=0.014)$. The instructions contain many medical terms that may be difficult for ordinary workers to understand. It is necessary then to prepare easy-to-comprehend instructions. Furthermore, it is necessary to study how much medical knowledge workers have in relation to their health management.

The degree of examinees' satisfaction significantly correlated with the fear of lifestyle-related diseases $(p=0.009)$. This result contradicts our hypothesis. We initially hypothesized that those feeling fear of lifestyle-related diseases would have considerable expectations about general health checkups and thus desire for more detailed instructions.

In the field of behavioral science, a health belief model ${ }^{13-16}$ ) was suggested for describing various preventive health options of people, for example, subjects' decisions regarding influenza vaccination and women's cancer screening behavior. According to this health belief model, the perceived susceptibility to and perceived severity of diseases are major factors that encourage people to take appropriate preventive health measures.

When interpreting the results of this study with reference to the health belief model, it is considered that those feeling fear of lifestyle-related diseases strive to utilize general health checkups on a daily basis, so as to avoid such lifestyle-related diseases. Therefore, it was considered that they may already know how to read the checkup results. The occupational health staff needs to conduct campaigns to promote awareness regarding lifestyle-related diseases targeting workers unfamiliar with such diseases.

As people become older, their physical functions deteriorate; therefore, there may be a considerable difference in the recognition of the importance of general health checkups between young and elderly people. Even if there were no statistically significant differences, it would be necessary to discuss the issue of general health checkups. For example, young people do not feel any deterioration of their physical functions; therefore, they might not be as willing to undergo general health checkups as elderly people. Consequently, there is a possibility that young people would evaluate their degree of satisfaction without considering the instructions carefully. Moreover, they would not feel the need to give a negative answer, so they might evaluate their 
degree of satisfaction as sufficient. Assuming that there is such a tendency, the answers would differ considerably between young and elderly people. We would like to address this issue in future studies.

In this study, we did not employ random sampling, so the data were not generalized. In addition, the ratio between the workers $39 \mathrm{yr}$ old or younger and the workers over $40 \mathrm{yr}$ old was approximately 5:1 in this survey. That is, the subjects were mainly young people. Age may be a factor that has a considerable effect on the recognition of the importance of general health checkups. This is the limitation of this study.

The adjusted $\mathrm{R}$ square value was low (0.064). This indicates that independent variables cannot describe dependent variables to a sufficient degree. Therefore, it is necessary to conduct further analyses of the items in the questionnaire.

\section{Acknowledgements}

The authors thank all those who helped conduct this study at the machine manufacturing plant and from the medical examination institution.

\section{References}

1) Irie M, Miyata M, Nagata S, Mishima N, Ikeda M, Hirayama S (1997) Psychosocial evaluation on the correct recollection of periodic medical checkups of workers. 1. The ratio of correctly recalled results of medical checkups. San Ei Shi 39, 193-202 (in Japanese with English abstract).

2) Irie M, Nagata S, Miyata M, Ikeda M, Hirayama S (1998) Psychosocial evaluation on the correct recollection of periodic medical checkups of workers. 2. Long-term change in the recalled results of medical checkups. San Ei Shi 40, 75-84 (in Japanese with English abstract).

3) Likert R (1931) A technique for the measurement of attitudes. In: Archives of Psychology, Columbia University Press, New York.

4) Alexander JA, Lichtenstein R, Oh HJ, Ullman E (1998) A causal model of voluntary turnover among nursing personal in longterm psychiatric settings. Res Nurs Health 21, 415-27.

5) Fang Y (2001) Turnover propensity and its causes among Singapore nurses: an empirical study. Int J Hum Resour Manage 12, 859-71.

6) Cavanagh SJ, Coffin DA (1992) Staff turnover among hospital nurses. J Adv Nurs 17, 1369-76.

7) Kudo Y, Satoh T, Hosoi K, Aizawa Y (2004) Factors associated with satisfaction among participants in a periodical worksite health check-up in Japan. J Occup Health 46, 461-9.

8) Hasegawa M, Sugita S (1993) Factors determining patient satisfaction with their medical care. Byouinkanri 30, 231-9 (in Japanese with English abstract).
9) Imanaka Y, Araki S, Murata K, Nobutomo K (1993) Determinants of patient satisfaction and intention to continue service utilization. Analysis of a survey of outpatient at a general hospital. Nihon Koshu Eisei Zasshi 40, 624-35 (in Japanese with English abstract).

10) Cleary PD, McNeil BJ (1988) Patient satisfaction as an indicator of quality care. Inquiry $\mathbf{2 5}, 25-36$.

11) Pascoe GC (1983) Patient satisfaction in primary health care: a literature review and analysis. Eval Program Plann 6, 185-210.

12) Ezaki T, Honda S, Hashimoto H, Jahng D (1999) Employee's satisfaction and the influential process factor during regular health check-up by contracted industrial association. San Ei Shi 41, 159-65 (in Japanese with English abstract).

13) Rosenstock IM (1974) Historical origins of the health belief model. In: The health belief model and personal health behavior, Becker MH (Eds.), 1-8, Charles B. Slack, New Jersey.

14) Rosenstock IM (1974) Health belief model and preventive health behavior. In: The health belief model and personal health behavior, Becker MH (Eds.), 27-59, Charles B. Slack, New Jersey.

15) Nexoe J, Kragstrup J, Sogaard J (1999) Decision on influenza vaccination among the elderly. A questionnaire study based on the Health Belief Model and the Multidimensional Locus of Control Theory. Scand J Prim Health Care 17, 105-10.

16) Murray M, McMillan C (1993) Health beliefs, locus of control, emotional control and women's cancer screening behaviour. Br J Clin Psychol 32, 87-100.

\section{Appendix 1 Items of the Questionnaire (The original version is in Japanese)}

Question set 1. Place a check mark in the $\square$, or give the most suitable response to the following questions.
1. Age:
( years old)

2. Gender:

$\square$ Male $\quad \square$ Female

3. Marital status: $\quad \square$ Married $\square$ Single

4. Do you remember receiving a result card with abnormal findings after a health checkup?
$\square$ Yes
No

5. Describe your routine work: blue-collar worker engaged mainly in on-site tasks or white-collar worker doing mainly deskwork?

$\square$ Blue-collar worker $\square$ White-collar worker

6. Have you ever been diagnosed with a lifestyle-related disease (caused by poor lifestyle habits) by a physician?

$$
\square \text { Yes } \square \text { No }
$$

Question set 2. Circle your answers concerning your views of health.

1. My general health condition is:
5. Good
4. Somewhat good
3. Average
2. Somewhat poor
1. Poor 
2. My interest in health is:
5. Considerable
4. Moderate
3. Average
2. Little
1. None

3. My knowledge of health management is:
5. Considerable
4. Moderate
3. Average
2. Little
1. None

4. My fear of lifestyle-related diseases (caused by poor lifestyle habits) is:
5. Considerable
4. Moderate
2. Little
1. None

Question 3. When you are notified of your results of general health checkups, you also receive instructions on how to read the checkup results. Were the explanations of the content sufficient? Circle your answer.

5. Definitely sufficient 4. Somewhat sufficient

3. Neither sufficient nor insufficient

2. Somewhat insufficient 1. Definitely insufficient 


\section{Appendix 2 Instructions on How to Read Results of General Health Checkups}

\section{For Your Health and Happiness}

Thank you for using this health center.

We all wish to lead a happy and healthy life. In order to maintain a state of good health, it is desirable that we should have regular medical examinations, take health checks, and lead a healthy life.

Here are the results of your recent medical examinations. We hope that they will help you to take care of your health. Even if no abnormalities were found this time, this does not mean that your future health is guaranteed. Please undergo a medical examination once a year and make efforts to maintain your good health. In addition, even if no abnormalities were found, we recommend that you consult a doctor if you are aware of any symptoms troubling you.

※ The standard criteria listed for each test may vary according to the medical institution.

How to read the results of medical examinations

\begin{tabular}{|c|c|c|c|c|}
\hline \multirow{4}{*}{$\begin{array}{c}\text { Test } \\
\text { Body measurements }\end{array}$} & \multicolumn{3}{|c|}{ Classification of results } & \multirow{4}{*}{$\begin{array}{l}\text { Main illnesses indicated by an abnormal result and lifestyle guidance } \\
\text { Being overweight causes lifestyle-related diseases; there is a } \\
\text { close relationship between obesity and diseases such as diabetes, } \\
\text { hyperlipemia, gout, high blood pressure, arterial sclerosis, and } \\
\text { heart disease. It is rare for obesity to be caused by an illness. } \\
\text { In most cases, obesity is the result of an excessive calorie intake } \\
\text { due to overeating; so, attention should be paid to the daily diet } \\
\text { and excrcise. }\end{array}$} \\
\hline & \multicolumn{2}{|c|}{ A No abnomalities } & $18.5-24.9$ & \\
\hline & \multicolumn{2}{|c|}{ B Practically normal } & - & \\
\hline & \multicolumn{2}{|c|}{$\begin{array}{l}\text { C Continued observation } \\
\text { required }\end{array}$} & $\begin{array}{l}>25.0 \\
<18.5\end{array}$ & \\
\hline Eyesight & \multicolumn{3}{|c|}{$\begin{array}{l}\text { In cases of impaired vision, this is measured while being } \\
\text { corrected by glasses, etc. }\end{array}$} & $\begin{array}{l}\text { People who habitually suffer from cye strain should consult an } \\
\text { ophthalmologist. }\end{array}$ \\
\hline Hearing & \multicolumn{3}{|c|}{$\begin{array}{l}\text { Findings in } 30 \mathrm{~dB} \text { at } 1000 \mathrm{~Hz} \text { stimulation and/or } 40 \mathrm{~dB} \\
\text { at } 4000 \mathrm{~Hz} \text { ranges indicate below average hearing. }\end{array}$} & $\begin{array}{l}\text { Hearing ability decreases with age; over the age of } 50 \text {, the range } \\
\text { of } 4000 \mathrm{~Hz} \text { and above is also reduced. People with hearing } \\
\text { difficulties are advised to consult an otologist. }\end{array}$ \\
\hline \multirow[t]{2}{*}{$\begin{array}{l}\text { Blood pressure } \\
\text { measurements }\end{array}$} & $\begin{array}{l}\text { Iligh blood } \\
\text { pressure }\end{array}$ & $\begin{array}{l}\text { Upper: } \\
\text { Lower }\end{array}$ & $\begin{array}{l}\text { Requires treatment. } \\
\text { Please consult a } \\
\text { doctor. }\end{array}$ & \multirow{2}{*}{$\begin{array}{l}\text { Blood pressure is affected by genetics and constitution, can vary } \\
\text { according to firect sunlight or the season, and can be raised hy } \\
\text { mental stress and excitement. It is important to cherk blood } \\
\text { pressure on a number of occasions rather than by a single check. } \\
\text { People with a high blood pressure should follow a regular } \\
\text { lifestyle and relax mentally. It is also important to reduce } \\
\text { salt intake, get plenty of sleep, and exercise. Please also watch } \\
\text { your weight. }\end{array}$} \\
\hline & $\begin{array}{l}\text { Raised blood } \\
\text { pressure }\end{array}$ & $\begin{array}{l}\text { Upper: } \\
\text { Lower }\end{array}$ & $\begin{array}{l}\text { Requires } \\
\text { observation. Please } \\
\text { measure blood } \\
\text { pressure once a } \\
\text { month. }\end{array}$ & \\
\hline Lipid test & \multicolumn{3}{|c|}{$\begin{array}{l}\text { More detailed tests are required when total cholesterol or } \\
\text { triglycerides are above, or below, the normal range, or } \\
\text { if there is a low HDL-C. When the results of more } \\
\text { detailed tests show an abnormality, the overall verdict is } \\
\text { that continued observation and further medical consultation } \\
\text { are required. }\end{array}$} & $\begin{array}{l}\text { An increase in these lipids means an increased chance of obesity } \\
\text { and developing arteriosclerosis, heart disease, and diabetes, etc. } \\
\text { Some triglycerides are synthesized in the liver and some are } \\
\text { acquired from food. People with an excess of them should avoid } \\
\text { too high an intake of animal fats, alcohol, and sugar. }\end{array}$ \\
\hline Liver function check & \multicolumn{3}{|c|}{$\begin{array}{l}\text { More detailed tests are required when any values above } \\
\text { the normal range are shown for any of the items. The } \\
\text { ovcrall verdict is that continued obscrvation and further } \\
\text { medical consultation are required for people whose } \\
\text { results show some abnormality. Particularly high values } \\
\text { in the initial test require a re-examination; please consult } \\
\text { a doctor as soon as possible. Please take more detailed } \\
\text { tests when HBs antigens are at } 0.05 \text { or higher, or if } \\
\text { HCV antibodies are present, and follow the doctor's } \\
\text { instructions. }\end{array}$} & $\begin{array}{l}\text { The role of the liver is to ensure the synthests of nutrients } \\
\text { needed by the body, as weIl as to neutralize toxins and bodily } \\
\text { waste. CO', ALI', and } y \text {-G'l'P are kinds of cnzymes present in } \\
\text { liver cells; they increase when the liver function is impaired. } \\
\text { Alcohol is a major factor in increased } \gamma \text {-GTP. A high level of } \\
\text { ZTT is shown when there is an increase in blood protein } \\
\text { globulin due to hepatitis or liver cirrhosis, etc. Cholinesterase } \\
\text { shows damage to the hepatic parenchyma. A positive result for } \\
\text { HBs antigens and HCV antibodies indicates Hepatitis B and } \\
\text { Hepatitis C infection. Urobilinogen also becomes positive when } \\
\text { there is hepatitis. TP shows the total blood serum protein, and } \\
\text { total bilirubin shows the strength of jaundice in the blood serum. } \\
\text { Liver ailments are known to be caused by such things as viral } \\
\text { infections, overwork, alcohol, excessive intake of medicines, and } \\
\text { malnutrition, so care should be taken in daily life. }\end{array}$ \\
\hline Diabetes & \multicolumn{3}{|c|}{$\begin{array}{l}\text { When urinary sugar is }(2+) \text { or higher, or when there is } \\
\text { a high level of blood sugar or HbAlc, detailed tests are } \\
\text { required. The presence or absence of diabetes is } \\
\text { detcrmined by a sugar tolcrance test. }\end{array}$} & $\begin{array}{l}\text { If the sugar tolerance test reveals a diabetic pattern, it is } \\
\text { necessary to avoid overeating and to take appropriate exercise to } \\
\text { avoid obesity and maintain an average weight. Medical treatment } \\
\text { becomes nccessary as the illness progresses. }\end{array}$ \\
\hline Uric acid & \multicolumn{3}{|c|}{$\begin{array}{l}\text { More detailed tests are made when there are higher than } \\
\text { the normal range. }\end{array}$} & High levels of uric acid in the blood may lead to atacks of gout. \\
\hline Blood test & \multicolumn{3}{|c|}{$\begin{array}{l}\text { Values higher or lower than the normal range require } \\
\text { more detailed tests. } \Lambda \text { general blood profile is performed, } \\
\text { and, in cases where there is an abnormality, continued } \\
\text { observation and a medical consultation are shown in the } \\
\text { overall verdict. }\end{array}$} & $\begin{array}{l}\text { Red blood rells, hemoglobin, and hematocrit are decreased by } \\
\text { anemia. Anemia may result from bleeding due to alimentary } \\
\text { track ulcers, cancer, and hemornhoids, etc., as well as after } \\
\text { childbirth and from uterine fibroids, pregnancy, and malnutrition, etc. } \\
\text { Iron deficiency anemia may be found in females. } \\
\text { MCV, MCH, and MCHC help to establish the cause of anemia. } \\
\text { A blood profile helps to establish the illness causing the } \\
\text { abnormal whice blood cell count. }\end{array}$ \\
\hline
\end{tabular}




\begin{tabular}{|c|c|c|}
\hline Test & Classification of results & Main illnesses indicated by an abnormal result and lifestyle guidance \\
\hline Urine, renal system & $\begin{array}{l}\text { When urine protein is }(2+) \text { or more, or occult blood }(2+) \\
\text { or more, a microscopic test of sedimentation is } \\
\text { performed. When there are high values for urea nitrogen } \\
\text { and creatinine, and more detailed tests reveal } \\
\text { abnormalities, the overall verdict will be continued } \\
\text { observation and a medical consultation. }\end{array}$ & $\begin{array}{l}\text { The urine protein and occult blood are indices for kidney and } \\
\text { urinary tract disorders, such as kidney stones, bacterial infection } \\
\text { in the urinary tract, or bladder cancer. The kidneys are important } \\
\text { organs that expel body waste. Urea nitrogen and creatinine serve } \\
\text { as indices to reveal the extent of the damage to renal function. }\end{array}$ \\
\hline Feces examination & $\begin{array}{l}\text { More detailed tests are required if higher values than the } \\
\text { nomal range are returned. }\end{array}$ & $\begin{array}{l}\text { A positive response to fecal blood signifies bleeding in the } \\
\text { alimentary canal. Its main use is the early detection of colon } \\
\text { polyps, ulcers, and cancer. }\end{array}$ \\
\hline Pancreas & $\begin{array}{l}\text { More detailed tests are required if higher values than the } \\
\text { normal range are returned. }\end{array}$ & $\begin{array}{l}\text { Values rise due to pancreatic disorders (pancreatitis, pancreatic } \\
\text { cancer, etc.) or mumps. }\end{array}$ \\
\hline Lung function & $\begin{array}{l}\text { A deterioration in lung function is suspected when the } \\
\text { values are lower than the normal range, and more detailed } \\
\text { tests are required. }\end{array}$ & $\begin{array}{l}\text { The lung capacity ratio and forced expiratory volume percentage } \\
\text { in one second are reduced by chronic respiratory disorders such } \\
\text { as emphysema, asthma, and chronic bronchitis. }\end{array}$ \\
\hline Inflammatory response & $\begin{array}{l}\text { More detailed tests are required if higher values than the } \\
\text { normal range are returned. }\end{array}$ & $\begin{array}{l}\text { CRP is a protein that appears when there is internal } \\
\text { inflammation. RA is mainly of use in the diagnosis of chronic } \\
\text { rheumatoid arthritis. Blood ccll sedimentation is accelerated by } \\
\text { inflammation, malnutrition, and anemia. }\end{array}$ \\
\hline ECG & $\begin{array}{l}\text { People judged to require more detailed tests should take } \\
\text { an exercise electrocardiogram and other tests; those } \\
\text { judged to require further medical consultation should } \\
\text { consult a doctor. }\end{array}$ & $\begin{array}{l}\text { An ECG examines heart movement, arrhythmia, cardiac } \\
\text { hypertrophy, and the heart muscle. People who experience } \\
\text { chest pain or chest pressure, palpitations, or shortness of breath } \\
\text { need to consult a doctor. }\end{array}$ \\
\hline Cytological diagnosis & $\begin{array}{ll}\text { I, II } & \text { Normal } \\
\text { III a, III b } & \text { Re-test } \\
\text { IV. V } & \text { More detailed tests, consult a gynecologist. }\end{array}$ & $\begin{array}{l}\text { This helps with the early detection of uterine cancer and to } \\
\text { diagnose fibroids. }\end{array}$ \\
\hline Breast examination & $\begin{array}{l}\text { If something is found, please consult a surgeon } \\
\text { (more detailed tests required). }\end{array}$ & $\begin{array}{l}\text { This helps with the early detection of breast cancer and the } \\
\text { diagnosis of mammary gland diseases. }\end{array}$ \\
\hline
\end{tabular}

Supplementary information

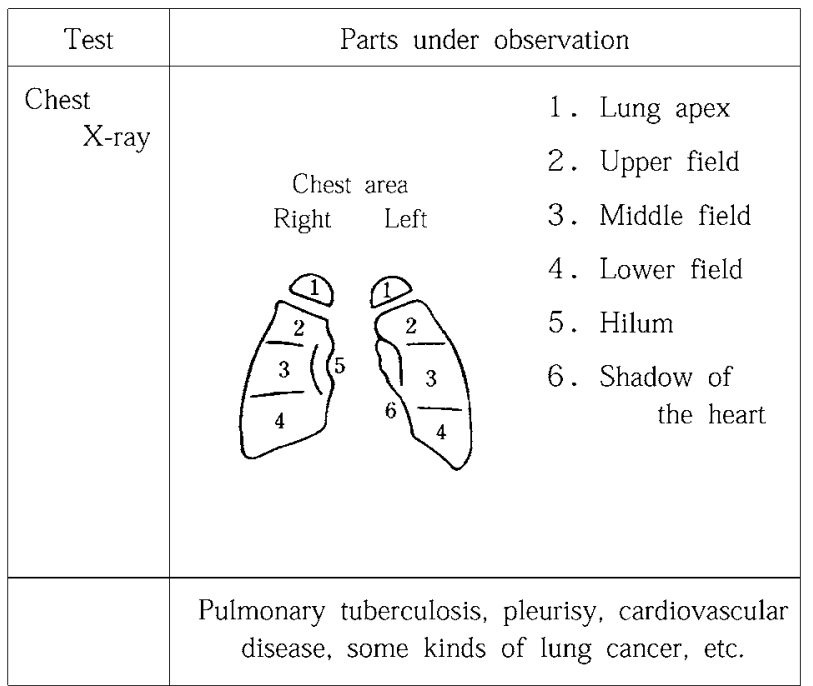

\begin{tabular}{|c|c|c|}
\hline Test & \multicolumn{2}{|c|}{ Parts under observation } \\
\hline $\begin{array}{l}\text { Stomach } \\
\text { X-ray }\end{array}$ & Stomach area & $\begin{array}{l}\text { 1. Esophagus } \\
\text { 2. Cardia } \\
\text { 3. Fundus } \\
\text { 4. Gastric corpus } \\
\text { 5. Gastric angle } \\
\text { 6. Antrum } \\
\text { 7. Pylorus } \\
\text { 8. Duodenal bulb } \\
\text { 9. Duodenal loop }\end{array}$ \\
\hline & Stomach ulcer, & lcer, gastric tumor \\
\hline
\end{tabular}

【Explanation of the result classifications】

A No abnormalities have been found within the scope of these tests.

B There was a slight deviation from the norm, but not enough to have any effect on your daily life.

C Take care in your daily life and keep this under observation.

D Medical treatment is required.

E More detailed tests are required.

F Please continue with your current course of treatment. 